\title{
Brief review: Coronary drug-eluting stents and anesthesia
}

\author{
[Article de synthèse court: Les tuteurs coronariens actifs et l'anesthésie]
}

Aparna R. Dalal MD, Stanlies D’Souza MD, Mark S. Shulman MD

Purpose: Anesthesiologists managing patients with drug-eluting stents (DES) face the challenge of balancing the risks of bleeding vs perioperative stent thrombosis (ST). This article reviews DES and the influence of antiplatelet medications related to their use. A perioperative management algorithm is suggested. Novel P2YI 2 antagonists currently under investigation, including cangrelor and prasugrel are considered, as well as their potential role in modification of perioperative cardiovascular risks and management of patients with DES.

Source: A PubMed search of the relevant literature over the period 1985-2005 was undertaken using the terms "drug-eluting stent", "coronary artery stent", "bare metal stent", "antiplatelet medication”, "aspirin”, “clopidogrel.”

Principal findings: Delayed re-endothelialization may render both sirolimus-eluting and paclitaxel-eluting stents susceptible to thrombosis for a longer duration than bare metal stents. Stent thrombosis may be associated with resistance to antiplatelet medication. In patients with a DES, a preoperative cardiology consultation is essential. Elective surgery should be postponed if the duration between DES placement and noncardiac surgery is less than six months. For semi-emergent procedures, both aspirin and clopidogrel should be continued during surgery unless clearly contraindicated by the nature of the surgery. If the risk of bleeding is high, then modification of antiplatelet medications should be considered on a case-by-case basis.

Conclusion: A profound increase in the number of patients with DES requires anesthesiologists to be familiar with their associated antiplatelet medications, and strategies for risk modification of ST and possible hemorrhagic complications in the perioperative setting.
Objectif: Les anesthésiologistes qui prennent en charge des patients porteurs de tuteurs coronariens actifs (TCA) font face au défi d'évaluer le risque de saignement en regard du risque de thrombose du tuteur dans la période périopératoire. Cet article traite des TCA et de l'influence des agents antiplaquettaires utilisés concurremment. Un algorithme de prise en charge est présenté. Les nouveaux antagonistes P2Y I 2 maintenant à l'essai, comme le cangrelor et le prasugrel, sont présentés, ainsi que leur rôle éventuel sur la modification du risque cardiovasculaire périopératoire et de la prise en charge des patients avec TCA.

Source : Une recherche d'articles pertinents à l'aide de PubMed pour la période 1985-2005 a été entreprise en utilisant les termes "drug-eluting stent", "coronary artery stent", "bare metal stent", "antiplatelet medication", "aspirin", "clopidogrel."

Constatations principales: Les tuteurs au sirolimus et au paclitaxel retardent la réendothélialisation. Ils sont donc plus susceptibles de former une thrombose plus longtemps que les tuteurs métalliques nus. Une thrombose due au tuteur peut entraîner une résistance aux agents antiplaquettaires. Une consultation en cardiologie est essentielle pour les patients avec un TCA. Une chirurgie réglée doit être reportée pour les patients porteurs de TCA depuis moins de six mois. Pour les urgences relatives, il est recommandé de poursuivre le traitement à l'aspirine et au clopidogrel à moins que le type de chirurgie ne le contre-indique. Si le risque de saignement est élevé, une modification du traitement antiplaquettaire doit être envisagée au cas par cas.

Conclusion : À cause du nombre croissant de patients porteurs de TCA, les anesthésiologistes doivent se familiariser avec les agents antiplaquettaires et avec les stratégies visant à modifier le risque de thrombose et de complications hémorragiques possibles dans le cadre d'une chirurgie.

From the Department of Anesthesiology and Pain Medicine, Caritas St. Elizabeth's Medical Center, Boston, Massachusetts, USA. Address correspondence to: Dr. Aparna R. Dalal, Department of Anesthesiology and Pain Medicine, Caritas St. Elizabeth's Medical Center, 736 Cambridge Street, Boston, MA 02135, USA. Phone: 617-789-2777; Fax: 617-254-6384; E-mail: aparnadalal@yahoo.com Accepted for publication January 26, 2006.

Revision accepted July 6, 2006.

Final revision accepted July 24, 2006. 
$\mathrm{P}$ ERCUTANEOUS coronary intervention (PCI) now surpasses coronary artery bypass grafting $(\mathrm{CABG})$ as the most frequent revascularization procedure for coronary artery disease $(\mathrm{CAD})$. Prior to the introduction of drugeluting stents (DES), patients with multivessel CAD requiring revascularization would often undergo CABG surgery instead of PCI because of concerns regarding restenosis with bare metal stents (BMS). Other factors such as left main disease, diabetes mellitus, and technical feasibility also influenced the decision to proceed with CABG surgery. In the current era of DES, it is likely that surgery will continue to be performed only for more complex subsets. Replacing CABG as the preferred therapy for two- and threevessel CAD has enormous potential for patient wellbeing, productivity, and cost-savings to the health care system. In the United States, the reimbursement rates for CABG and PCI with DES differ by approximately $\$ 15,000{ }^{1}$ Thus, the market for DES is expanding exponentially, and DES are now available in more than 80 countries worldwide.

Drug-eluting stents have significantly reduced the incidence of in-stent restenosis, but are also associated with the potential for an increased incidence of late stent thrombosis (ST). This is especially true in patients who require non-cardiac surgery and discontinue their antiplatelet therapy. The prognosis of patients who develop late ST is poor, and these individuals face a significant mortality risk. ${ }^{2}$ While perioperative mortality rates specifically related to DES have yet to be determined, the problem recently prompted the U.S. Food and Drug Administration (FDA) to issue a physician communication regarding this issue. ${ }^{\mathrm{A}}$

Anesthesiologists are likely to encounter more patients preoperatively who have been treated with DES. Several important issues emerge when dealing with perioperative patients who have an implanted DES. These include defining the safe period after which a recently stented patient can undergo elective surgery, modification of antiplatelet therapy for semiemergent procedures, and obtaining a preoperative cardiology consultation. Evaluation of perioperative cardiovascular risk is essential, even if antiplatelet medication is continued throughout the perioperative period. Guidelines regarding perioperative management of DES and the concurrent use of antiplatelet agents have yet to be established. This article reviews

A FDA Patient Safety News: Show \# 43, September 2005. Importance of antiplatelet therapy with drug-eluting stents. Available from URL; www.fda.gov/psn. the best currently available information on DES, required antiplatelet therapy, and anesthetic implications of DES. An approach to the perioperative management of the patient with a DES is presented. Finally, novel P2Y12 antagonists are considered, and their potential impact on perioperative risk and management is reviewed. A PubMed search of the relevant literature over the period 1985-2005 was undertaken using the terms "drug-eluting stent", "coronary artery stent", "bare metal stent", "antiplatelet medication", "aspirin", and "clopidogrel."

\section{Advantages of DES over BMS}

Coronary balloon angioplasty is limited by vessel recoil, spasm, and abrupt closure. Bare metal stents may prevent these complications, however, they are associated with restenosis rates of $25-30 \% .^{3}$ Restenosis is the narrowing of a stented coronary artery due to the development of neo-intimal hyperplasia within the stent. The combination of arterial trauma and foreign body response results in an acute and chronic inflammatory reaction. Activation of cytokines and growth factors results in smooth muscle migration and proliferation results in scar tissue formation within the stent, thus narrowing the vessel lumen. This process generally begins to occur in the first six to eight weeks after stenting, ${ }^{4}$ but can be seen beyond one year following stent placement. ${ }^{5}$

Drug-eluting stents were introduced to reduce the rate of restenosis. The drug eluted from the stent inhibits smooth muscle and endothelial cell proliferation, ${ }^{6}$ thereby delaying the inflammatory response. The stent then becomes layered with endothelial cells, albeit at a slower pace than seen with BMS. Endothelialization of the stent causes the device to be incorporated into the artery, becoming more a part of the vessel rather an implanted foreign body. Theoretically, complete healing of DES may take up to two years. ${ }^{7}$

Two stents have received approval from both the Food and Drug Administration in the United States and the Conformite Europeene (CE) from British Standards Institution. Taxus (Boston Scientific, Natick, MA, USA) and Cypher (Cordis, Miami, FL, USA) are currently manufacturing DES while a third stent, Endeavor (Medtronic, Minneapolis, MN, USA) has recently acquired the CE mark, and is expected to receive FDA approval in the near future. Cypher is a sirolimus-eluting stent (SES). Sirolimus is a natural fermentation product produced by the fungus Streptomyces hygroscopicus. It is a macrolide antibiotic with potent antifungal, immunosuppressive, and antimitotic activities. ${ }^{8}$ It produces cell-cycle arrest in the 
TABLE I

\begin{tabular}{llll}
\hline Trial and no. of patients & Stent & TLR $(\%)$ & TVF(\%) \\
\hline${\text { Taxus } \mathrm{IV}^{14}(n=1,314)}$ & Taxus stents & 7.1 & 10 \\
Sirius $^{15}(n=1,058)$ & BMS & 17.1 & 19.4 \\
Endeavor $\mathrm{II}^{16}(n=1,197)$ & Cypher stents & 8.5 & 9.8 \\
& BMS & 26.7 & 24.8 \\
& Endeavor stent & 7.8 & 9.9 \\
\hline
\end{tabular}

Target lesion revascularization (TLR) is the need for a repeat procedure in the stented area. Target vessel failure (TVF) represents the key clinical outcome, and is defined as the composite of death, Q-wave myocardial infarction, and clinically driven repeat revascularization of the target vessel. ${ }^{13}$ BMS $=$ bare metal stents.

$\mathrm{Gl} / \mathrm{S}$ phase transition and is regarded as a cytostatic agent. Sirolimus-eluting stents are coated with 140 $\mu \mathrm{g}$ of sirolimus per square centimetre, which slowly eludes over a course of four to six weeks. The Taxus stent is a paclitaxel-eluting stent (PES). Paclitaxel is an anti-neoplastic drug that is derived from a Pacific Yew Tree (Taxus brevifolia). It produces cell-cycle arrest in the $G_{2} / M$ phase transition and is regarded as a cytotoxic agent. ${ }^{9,10}$ Paclitaxel-eluting stents are coated with paclitaxel $100 \mu \mathrm{g} \cdot \mathrm{cm}^{-2}$, with a bimodal release that is completed in approximately two weeks. ${ }^{11}$ Endeavor from Medtronics elutes zotarolimus, a sirolimus analogue. Other available DES include Xience V from Guidant which elutes everolimus, and TriMaxx/ Zomaxx from Abbott which elutes biolimus.

The function of stents can be evaluated in terms of target lesion revascularization and target vessel failure. Clinical trials comparing DES with BMS have been conducted $^{12-15}$ (Table I). There is now an abundance of clinical trial data showing the superiority of DES over BMS for the prevention of in-stent restenosis.

A meta-analysis of randomized trials has demonstrated that the rates of death, myocardial infarction (MI), and ST for both SES and PES stents are similar. The angiographic restenosis rate for SES was 9.3\% vs $13.1 \%$ for PES. Event rates for SES vs PES were 0.9\% and $1.1 \%$ respectively, for ST, $1.4 \%$ and $1.6 \%$ respectively for death; and $4.9 \%$ and $5.8 \%$ respectively for the composite of death or MI. ${ }^{16}$

To be effective, DES require a biocompatible polymer coating that can hold and release the drug in a time-controlled fashion. The drug is eluted in sufficient quantity to prevent cell accumulation and narrowing of the central lumen. This form of endovascular release also lessens the incidence of systemic side effects of the drug released from the stents. ${ }^{17}$ Since a DES is designed to delay the inflammatory response, thus reducing neo-intimal hyperplasia and in-stent

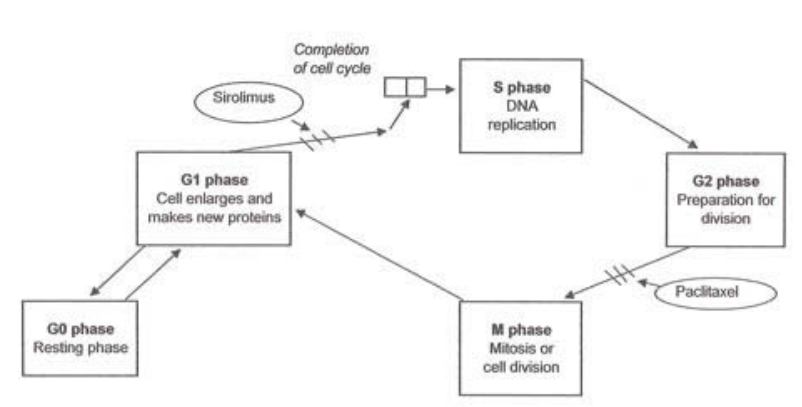

FIGURE 1 Schematic diagram depicting mechanism of action of sirolimus and paclitaxel. Sirolimus is a cytostatic agent and acts on Gl/S phase transition. Paclitaxel is a cytotoxic agent and acts on $\mathrm{G} 2 / \mathrm{M}$ phase transition. Both drugs produce cell cycle arrest.

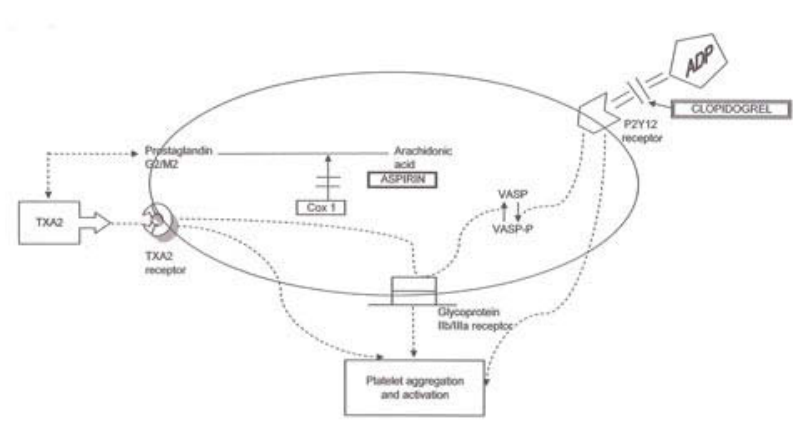

FIGURE 2 Schematic diagram depicting mechanisms of action of aspirin and clopidogrel. Aspirin blocks cyclooxygenase enzyme 1 (Cox-1) which converts arachidonic acid to prostaglandin $\mathrm{G} 2 / \mathrm{M} 2$. This leads to inhibition of thromboxane A2 (TxA2) production. Clopidogrel irreversibly inhibits the adenosine diphosphate (ADP) P2Y12 receptor. This leads to inhibition of phosphorylation of vasodilatorstimulated phosphoprotein (VASP). Glycoprotein IIb/IIIa receptor is not activated. Ultimately, platelet aggregation and activation is inhibited.

restenosis, the endothelialization of the stent may also be delayed, thereby potentially increasing the risk of subacute ST.

\section{Antiplatelet medications for DES}

Thrombus formation must be prevented with the use of appropriate medications until the stents have completely endothelialized. Platelets play a major role in thrombus formation after coronary stenting. 
Uncontrolled and progressive platelet activation and adhesion through a series of self-sustaining amplification loops may lead to intraluminal thrombus formation, vascular occlusion, transient ischemia, or infarction. ${ }^{18}$ Currently available antiplatelet agents interfere with specific steps in the activation process, including adhesion, release and/or aggregation, and have a measurable impact on the risk of arterial thrombosis that cannot be disassociated from an increased risk of bleeding. ${ }^{18}$

Aspirin binds to the enzyme cyclooxygenase (COX) preventing conversion of arachidonic acid to thromboxane (Figure 2). Clopidogrel and ticlopidine ${ }^{B}$ act on the adenosine diphosphate (ADP) receptor which contains P2Y1 and P2Y12 subtypes. The $\mathrm{P} 2 \mathrm{Y} 12$ receptor is responsible for the completion and amplification of the response to ADP and to all platelet agonists, including thromboxane, thrombin, and collagen. It plays a central role in the formation and stabilization of a thrombus. ${ }^{19}$ The stimulation of P2Y12 is also essential for ADP-mediated complete activation of glycoprotein (GP) IIb/IIIa and GP Ia/ IIa, and further stabilization of platelet aggregates. ${ }^{20}$ Thus, clopidogrel and ticlopidine irreversibly inactivate the P2Y12 receptor via the covalent binding of an active metabolite generated in the liver. ${ }^{21}$ Blocking ADP binding results in a coupled biochemical reaction that inhibits binding of fibrinogen to the GP $\mathrm{IIb} / \mathrm{III} a$ receptor on the platelet surface. Thus, the platelet is irreversibly modified, rendering it unable to aggregate.

The American College of Cardiology/American Heart Association (ACC/AHA) guidelines recommend that aspirin should be given to the patient with suspected ST elevation MI as early as possible, regardless of the strategy for reperfusion and regardless of whether additional antiplatelet agents are administered. ${ }^{22}$ True aspirin allergy is the only exception to this recommendation. Aspirin alone has little or no effect on angiographic or clinical restenosis, but longterm aspirin therapy is useful for secondary prevention of cardiovascular events. ${ }^{23}$ However, lower doses of aspirin, 75-100 mg, are used in combination with other antithrombotic agents. This is because a higher dose of aspirin is associated with increased risk of bleeding when used along with clopidogrel, without any added benefit. ${ }^{24}$ Platelet inhibition with aspirin lasts until a significant pool of new platelets is synthe-

B TICLID ${ }^{\circledR}$ (ticlopidine hydrochloride) Prescribing information. Available from URL; www.rocheusa.com/products/ticlid/ pi.pdf. sized. Complete recovery of platelet aggregation may occur in $50 \%$ of cases by day three and in $80 \%$ of cases by day four ${ }^{25}$ (Table II).

Clopidogrel therapy is initiated either prior to or immediately following the stenting procedure. Another thenopyridine derivative, ticlopidine, can also be used. Therapeutic effects are similar with these two drugs. However, ticlopidine is limited by side effects such as neutropenia and thrombocytopenia. ${ }^{26}$

As compared with conventional anticoagulant therapy, combined antiplatelet therapy after the placement of coronary artery stents reduces the incidence of cardiac events and hemorrhagic and vascular complications. ${ }^{27}$ Therefore, post-PCI, both aspirin and clopidogrel therapy are commenced. As aspirin and clopidogrel have different mechanisms of action, the combination therapy is more effective than using either agent alone to prevent ST. ${ }^{28}$ This combination therapy is more effective in preventing ST compared to aspirin and warfarin. ${ }^{29}$ Certain patients may also need anticoagulation for atrial fibrillation, post-MI cardiomyopathy, left ventricular or left atrial thrombus, history of previous cerebrovascular accident, and presence of mechanical aortic or mitral valves. The use of oral anticoagulation with warfarin and aspirin also appears to be acceptable. ${ }^{30}$

Clinical trials have shown that long-term clopidogrel administration significantly reduces major clinical events. ${ }^{31}$ The ACC/AHA guidelines recommend that for patients who have undergone PCI, clopidogrel, $75 \mathrm{mg}$ daily, should be given for at least one month following BMS implantation, for at least three months after SES, for six months after PES implantation, and for up to 12 months in patients who are not at high risk for bleeding. ${ }^{22}$ The duration of therapy varies for each stent and is based on the data from clinical trials used for FDA approval of that stent. The European Society of Cardiology (ESC) recommends six to 12 months of clopidogrel therapy after DES. ${ }^{7}$ Many cardiologists at our institution prescribe clopidogrel for at least one year after DES implantation, followed by lifelong aspirin therapy.

Clopidogrel $300 \mathrm{mg}$ loading dose should be administered at least six hours prior to the stenting procedure. ${ }^{32}$ Repeated doses of clopidogrel 75 $\mathrm{mg} \cdot \mathrm{day}^{-1}$ inhibit platelet aggregation with inhibition reaching a steady state between days three and seven following PCI. At steady state, the average inhibition level observed with clopidogrel $75 \mathrm{mg}$ daily is between $40-60 \%$. The observed bleeding time is typically prolonged by a factor of 1.7. ${ }^{\mathrm{C}}$

Clopidogrel is contraindicated in patients with active pathological bleeding. Infrequent complica- 
TABLE II Comparison of currently available P2Y12 antagonists with medications under investigation

\begin{tabular}{|c|c|c|c|c|}
\hline & Clopidogrel & Ticlopidine & $\begin{array}{l}\text { Prasugrel } \\
\text { (CS-747) }\end{array}$ & $\begin{array}{l}\text { Cangrelor } \\
(A R-C 69931 M X)\end{array}$ \\
\hline Status & Approved and marketed & Approved and marketed & $\begin{array}{l}\text { In production and yet } \\
\text { to be approved. Targeted } \\
\text { availability } 2007-2008\end{array}$ & $\begin{array}{l}\text { In production and yet } \\
\text { to be approved } \\
\text { Targeted availability } \\
2007-2008 \text {. }\end{array}$ \\
\hline Manufacturer & $\begin{array}{l}\text { Sanofi-Sythelabo / } \\
\text { Bristol-Myers Squibb } \\
\text { Company }\end{array}$ & Roche Laboratories Inc. & $\begin{array}{l}\text { Eli Lilly and Co, } \\
\text { Sankyo Pharma. }\end{array}$ & $\begin{array}{l}\text { The Medicines } \\
\text { Company }\end{array}$ \\
\hline Compound & Thienopyridine & Thienopyridine & Thienopyridine & $\begin{array}{l}\text { ATP derivative-P2T } \\
\text { purinoreceptor } \\
\text { antagonist }^{96}\end{array}$ \\
\hline Nature of drug & Prodrug & Prodrug & Prodrug & ----- \\
\hline Action on receptor & Irreversible & Irreversible & Irreversible & Reversible \\
\hline Action via & $\begin{array}{l}\text { Liver metabolite which } \\
\text { is a carboxylic acid } \\
\text { derivative. }{ }^{35}\end{array}$ & $\begin{array}{l}20 \text { liver metabolites, no } \\
\text { specific metabolite which } \\
\text { accounts for activity has } \\
\text { been isolated. } .^{20}\end{array}$ & $\begin{array}{l}\text { Liver metabolite } \\
\text { R-13872794 }\end{array}$ & Direct \\
\hline Dose & $\begin{array}{l}\text { Loading } 300 \mathrm{mg} \text {. } \\
\text { Daily } 75 \mathrm{mg} \text { OD }\end{array}$ & $250 \mathrm{mg}$ bid & $0.3-3 \mathrm{mg} \cdot \mathrm{kg}^{-1} 94$ & $\begin{array}{l}4 \mu \mathrm{g} \cdot \mathrm{kg}^{-1} \cdot \min ^{-1} \\
\text { infusion. }{ }^{2}\end{array}$ \\
\hline Daily dose with action & $\begin{array}{l}75 \mathrm{mg} \text { OD produces } \\
40-60 \% \text { platelet inhibition } \\
\text { between day } 3 \text { and day } 7 .{ }^{35}\end{array}$ & $\begin{array}{l}250 \mathrm{mg} \text { bid produces } \\
50 \% \text { platelet inhibition } \\
\text { within } 4 \text { days. }{ }^{20}\end{array}$ & $\begin{array}{l}10 \mathrm{mg} \text { oral dose daily } \\
\text { produces significant } \\
\text { platelet inhibition after } \\
2 \text { days. }{ }^{95}\end{array}$ & $\mathrm{NA}$ \\
\hline Recovery of platelet function & $\begin{array}{l}\text { Platelet function returns } \\
\text { to baseline } 5 \text { days after } \\
\text { discontinuation. }^{35}\end{array}$ & $\begin{array}{l}\text { Platelet function returns } \\
\text { to normal within two wks } \\
\text { of discontinuation. }{ }^{20}\end{array}$ & $\begin{array}{l}2 \text { days after } \\
\text { discontinuation }\end{array}$ & $\begin{array}{l}\text { Within } 60 \text { min of } \\
\text { discontinuation of } \\
\text { infusion. Plasma half } \\
\text { life }<9 \min ^{92}\end{array}$ \\
\hline Route of administration & Oral & Oral & Oral & Intravenous \\
\hline Onset of action & $\begin{array}{l}\text { Dose dependent } \\
\text { within } 2 \mathrm{hr}^{35}\end{array}$ & $\begin{array}{l}\text { Maximal platelet } \\
\text { inhibition }(60-70 \%) \\
\text { achieved after } 8-11 \text { days }^{20}\end{array}$ & $\begin{array}{l}\text { Dose dependent, } \\
30 \min ^{95}\end{array}$ & $\begin{array}{l}\text { At } 1 \mathrm{hr} \text { post-infusion, } \\
\text { mean inhibition of PA } \\
40.7 \pm 36.7 \%{ }^{92}\end{array}$ \\
\hline Antiaggregatory activity & Partial & Partial & Same as clopidogrel ${ }^{95}$ & $\begin{array}{l}\text { Complete platelet } \\
\text { inhibition } 91,92\end{array}$ \\
\hline Antithrombotic activity & Baseline-for comparison & Similar to clopidogrel & Greater than clopidogrel ${ }^{95}$ & Significant \\
\hline Potency & Baseline-for comparison & Lesser than clopidogrel & Greater than clopidogrel ${ }^{96}$ & $\begin{array}{l}\text { Greater than } \\
\text { clopidogrel }\end{array}$ \\
\hline $\begin{array}{l}\text { Major clinical phase } 2 \\
\text { and } 3 \text { trials }\end{array}$ & NA & NA & JUMBO-TIMI $26^{97}$ & $\begin{array}{l}\text { TMC-CAN-0402 } \\
\text { Results not yet } \\
\text { published. }\end{array}$ \\
\hline $\begin{array}{l}\text { Major frequent } \\
\text { complication other } \\
\text { than bleeding }\end{array}$ & 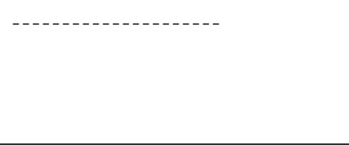 & $\begin{array}{l}\text { Life threatening } \\
\text { neutropenia, } \\
\text { agranulocytosis, aplastic } \\
\text { anemia, TTP. }\end{array}$ & Data not available & Data not available. \\
\hline
\end{tabular}

TTP = thrombotic thrombocytopenic purpura; ATP = adenosine 5' triphosphate.

tions include intracranial hemorrhage $(0.4 \%)$ and severe neutropenia $(0.5 \%)$. A rare complication after coronary stenting has been described where clopidogrel therapy produced thrombotic thrombocytopenic purpura (TTP). ${ }^{33}$ Clopidogrel-induced platelet activation and aggregation were observed in this patient, resulting in ST. The incidence of clopidogrel-induced TTP is very low (four cases per one million patients exposed). ${ }^{\mathrm{C}}$

\section{Resistance to antiplatelet medications}

The potential risk of ST in patients with DES who experience resistance to antiplatelet medication must be considered in the perioperative setting. Potential causes of aspirin resistance include complex

C PLAVIX $®$ (clopidogrel bisulfate) Prescribing information. Available from URL; http://products.sanofi-aventis.us/plavix plavix.html. 
drug interactions, genetic polymorphisms of COX-1 and other genes involved in thromboxane synthesis, up-regulation of non-platelet sources of thromboxane biosynthesis, and increased platelet turnover. ${ }^{34}$ Antiplatelet effects of aspirin are variable in different individuals and probably have a continuous and broad distribution as does blood pressure. Moreover, no test of platelet function is recommended to assess the antiplatelet effect of aspirin in an individual patient. ${ }^{14,34}$ Hence, there is no established cut-off at present to distinguish between the presence or absence of aspirin resistance. ${ }^{34}$

It has been proposed that the term clopidogrel resistance encompasses patients for whom the drug does not achieve its pharmacological effect, and failure of therapy reflects patients who have recurrent events on therapy ${ }^{35}$ Causes of clopidogrel resistance include genetic polymorphisms of the P2Y12 receptor and of CYP3As, accrued release of ADP, and up-regulation of other platelet activation pathways. ${ }^{36}$ The prevalence of clopidogrel non-response in patients is between $4 \%$ and $30 \% 24 \mathrm{hr}$ after administration. ${ }^{37-43}$ No single standard validated method is available to measure clopidogrel efficacy. ${ }^{36,44}$

Platelet function can be assessed by monitoring vasodilator-stimulated phosphoprotein, which directly measures the function of the clopidogrel target, the P2Y12 receptor, ${ }^{44}$ or using platelet aggregometry, flow cytometry of P-selectin, impedance aggregation, and the platelet function analyzer. ${ }^{34}$ Bleeding time is rarely used, as it is highly operator dependent and poorly reproducible. ${ }^{34}$

\section{CABG after failed percutaneous transluminal coronary angioplasty (PTCA)}

Patients may present for CABG after failed stent placement for events such as ongoing ischemia, threatened occlusion with significant myocardium at risk, hemodynamic compromise, foreign body in a critical anatomical position, and hemodynamic compromise in patients with impairment of the coagulation system. ${ }^{45}$ Such patients usually have received $75-325 \mathrm{mg}$ of aspirin, the dose variation depending on whether the patients was already on chronic aspirin therapy. A $300 \mathrm{mg}$ loading dose of clopidogrel is generally administered six hours prior to the PTCA. However, if given at the time of the procedure, clopidogrel may be supplemented with GP IIa/IIIb antagonists. ${ }^{32}$ Such patients presenting for CABG are at high risk for perioperative bleeding and are very likely to require perioperative transfusion therapy.
Non-cardiac surgery and drug eluting stents

Surgery for patients with DES should be performed at centres where interventional cardiology and cardiac surgery facilities are available at all times. Patients undergoing non-cardiac surgery soon after placement of coronary stents are at increased risk of ST in the perioperative period. This risk is clearly elevated when antiplatelet therapy is discontinued due to concerns of bleeding. The risk is also elevated, however, when antiplatelet therapy is continued. This may be a result of enhanced fibrin generation in the immediate postoperative period leading to a hypercoagulable state. ${ }^{46}$ Alternatively, if there are bleeding complications as a result of dual antiplatelet therapy, the bleeding can lead to hypotension and reduced perfusion through the stent, resulting in thrombosis.

Although there are no data which quantify the risks of surgery in patients receiving antiplatelet therapy, most cardiologists recommend that if surgery is necessary, dual-antiplatelet therapy should be continued perioperatively unless specifically contraindicated by the nature of the surgery, for example, intracranial procedures. The risk of ST will be increased in the perioperative period regardless of whether or not the antiplatelet therapy is continued.

It is essential that the anesthesiologist be part of the multidisciplinary team which determines the optimal time for surgery in these patients. The authors recommend an algorithmic approach to the clinical decisionmaking process as outlined in Figure 3. For all surgical patients who have undergone PCI, it is important to document when the stent was inserted and whether the patient received a BMS or DES. The duration of dual antiplatelet therapy should be confirmed whether aspirin monotherapy has been continued, while questioning for any history suggestive of antiplatelet medication resistance.

\section{Elective surgical procedures}

It is thought that all elective procedures should be delayed for at least four to six weeks in patients who have received a BMS. ${ }^{47}$ However, there are no guidelines from the AHA/ACC/ESC for the appropriate delay for non-cardiac surgery following coronary stenting with DES. In addition, this period may require variation according to the stent structure, polymer coating, and the type of drug eluted.

According to ESC, prolonged administration of clopidogrel (> six months) is mandatory to avoid late ST. ${ }^{7}$ The ESC also concludes that in patients undergoing urgent major non-cardiac surgery, DES should not be implanted and BMS are probably a safer choice. Thus, the authors conclude that elective 


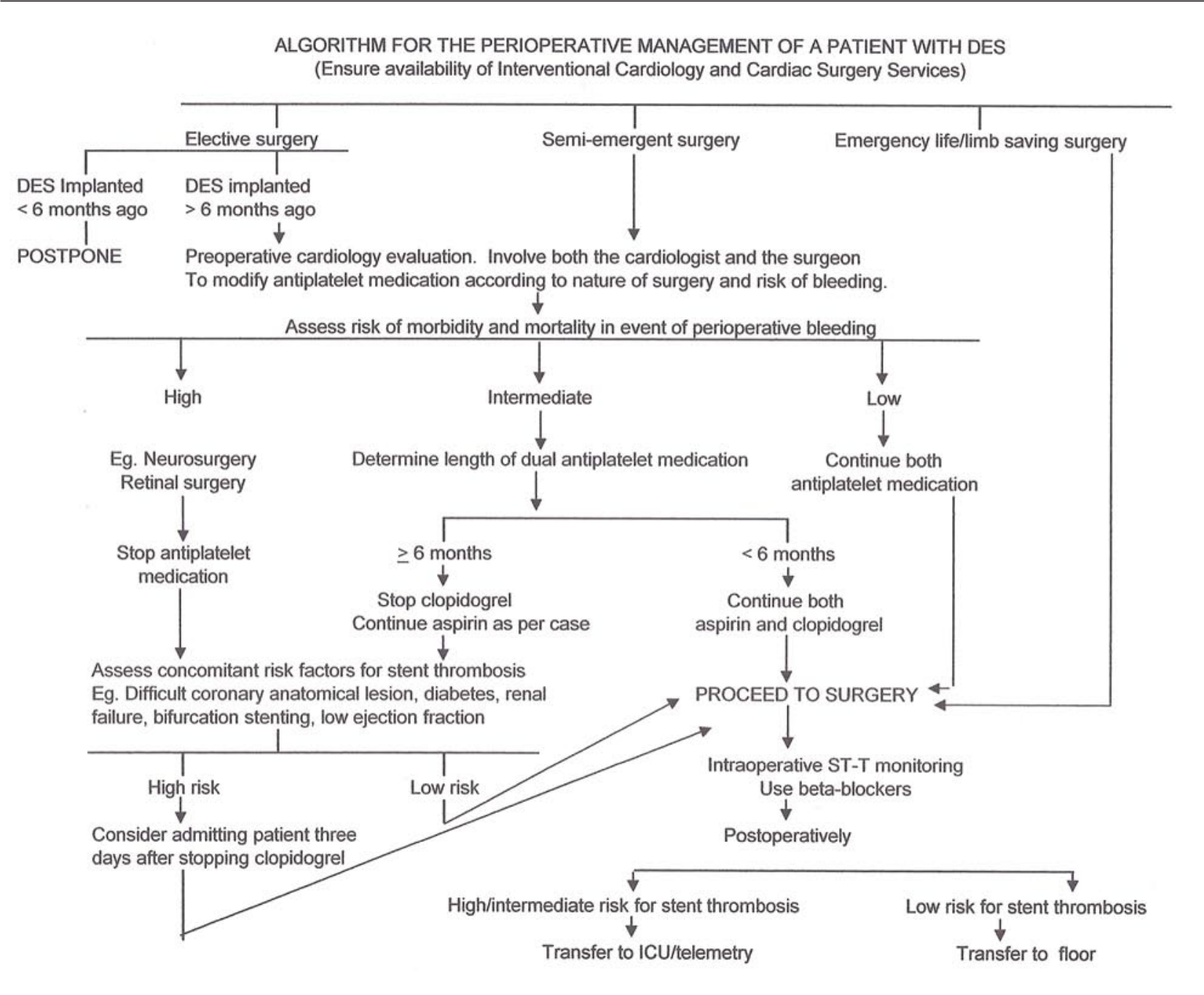

FIGURE 3 Algorithm for the perioperative management of a patient with drug-eluting stents (DES).

procedures should be delayed for at least six months in patients with DES. It is recommended that the risk of delayed re-endothelialization and ST be reviewed with both the surgeon and the patient.

The timing of elective surgery in patients with coronary stents should take into consideration both the time interval since DES insertion and the possible extent of perioperative adverse events. Preanesthetic evaluation for elective surgery in patients with DES plays a significant role in such decision-making and risk assessment. If there is no major risk of bleeding, all elective surgeries six months after DES implantation should be managed similarly to urgent surgery.
Patients should be duly informed of the risks and benefits of adjusting their antiplatelet therapy, and the potential for coronary restenosis in the perioperative setting.

\section{Urgent surgical procedures}

In patients presenting for urgent surgical procedures, modification of antiplatelet medication should be made on a case-by-case basis. If there is a high risk of perioperative bleeding producing significant morbidity, clopidogrel should be withheld for at least five days before surgery. The continuation of aspirin should be based on the nature of the surgery. 
If clopidogrel and aspirin have been taken for less than six months after stent placement, consideration can be given to admitting the patient to hospital approximately three days after stopping clopidogrel. This time frame allows recovery of platelet aggregation after aspirin therapy in $50 \%$ of cases by day three.$^{25}$ Moreover, attenuation of clopidogral induced antiplatelet effects begins within two days of discontinuing the medication. ${ }^{44}$ Related factors to consider include the estimated risk of ST and the impact of ST on overall morbidity and mortality, which depend on the vessel stented and the origin of its blood supply. It is likely that most patients who present for urgent surgery will already have been admitted preoperatively by surgical services. Subsequent monitoring by telemetry is warranted if there are concomitant factors that increase chances of ST such as bifurcated lesions, renal failure, diabetes, or a low ejection fraction.

If there is an intermediate risk of morbidity and mortality in event of perioperative bleeding, determine the length of dual antiplatelet medication: if less than six months, continue both medications; if more than six months discontinue clopidogrel and maintain aspirin therapy. Anatomical considerations of stent placement are also important. The interventional cardiologist may recommend that antithrombotic medications be continued despite significant risk of bleeding if the patient is deemed at high risk for ST according to the coronary vessel stented and the degree of difficulty in stenting the lesion due to its structure and location. It is important for the cardiologist to document such details for reference during future surgery. If there is no risk of life-threatening or significant perioperative bleeding, the antiplatelet medications should be continued throughout the perioperative period. This would, obviously, preclude the use of central neuraxial blocks. ${ }^{48}$

\section{Perioperative DES stent thrombosis}

Currently, the incidence of ST in patients with DES undergoing noncardiac surgery is unknown. Rodriguez et al. reported a $3.1 \%$ incidence of ST within the 18 months following stent implantation in 225 patients with multivessel CAD. ${ }^{49}$ The authors report three cases of ST in the first month, three others within the first year, and one additional case 30 months after stent placement. In patients who experienced this complication following discontinuation of antiplatelet therapy, six had an ST-segment elevation MI, and three died. Another recent report also highlighted the problem of ST. ${ }^{2}$ A total of 2,229 consecutive patients underwent successful DES implantation at three European hospitals over a 21-month period. At nine-month follow-up, 29 patients (1.3\%) had suf- fered ST, including 14 patients with subacute thrombosis $(0.6 \%)$, and 15 patients with late thrombosis $(0.7 \%)$. Of these 29 patients, 13 died. The incidence of complications was similar with sirolimus and paclitaxel stents. The case fatality ratio was $45 \%{ }^{2}$

Other studies examining ST with BMS show that clinical consequences of angiographic ST include a $64.4 \%$ incidence of death or MI at the time of ST and a six-month mortality of $8.9 \%{ }^{50}$ For clinically defined ST events, the associated six-month mortality is as high as $20.8 \%$. Due to such a high risk of death following ST, prevention of thrombosis is critical.

Stent thrombosis after SES implantation has been reported to occur at six hours to 375 days after the procedure, and usually within two weeks of discontinuation of antiplatelet medication. ${ }^{51}$ However, there has been a reported case of thrombosis 17 months after SES insertion where clopidogrel had been discontinued after eight months despite continued aspirin therapy. ${ }^{51}$ Late ST has also been reported 13 months after PES insertion, in spite of six months of dual antithrombotic therapy in this patient and lifelong aspirin monotherapy. ${ }^{52}$ There have also been reports of angiographically confirmed ST which occurred late after PES and SES insertion, resulting in MI..$^{53}$

There are data which link the risk of ST after DES implantation to stent length. ${ }^{54}$ Stenting across branch ostia, disruption of adjacent vulnerable plaques, and plaque prolapse can precipitate late ST. Impaired healing, i.e., failure to form a complete neo-intimal layer over stent struts, extends the window during which stents are prone to thrombosis. ${ }^{55}$ Angiographically proven late ST occurs with an incidence of at least $0.35 \%{ }^{56}$ No such cases were observed in patients with dual antiplatelet therapy, but the complication may occur in patients with stable antiplatelet monotherapy. Ortolani et al. ${ }^{57}$ reported that diabetics undergoing DES for focal lesions in small vessels (mean, $2.1 \mathrm{~mm}$ diameter) have an angiographic restenosis rate of $25 \%$. Although this rate was significantly better in comparison with BMS $(63 \%, P<0.002)$, the clinical major adverse cardiac event rate at eight months was $14 \%$.

Premature discontinuation of antiplatelet therapy (< six months for clopidogrel), renal failure, bifurcation stenting, diabetes, and low ejection fraction have been identified as potential predictors of thrombotic events in DES. ${ }^{2}$ Iakovou et al. devised a risk score for prediction of thrombosis after DES implantation. ${ }^{58}$ These variables were defined with concurrent antiplatelet therapy of aspirin and clopidogrel or ticlopidine. The five variables identified as predictors of ST were assigned a weighted integer, the sum of which constituted the risk score. These included: ejection 
fraction for each $20 \%$ decrease $=0.25$, status postbrachytherapy $=2.5$, diabetes $=4$, bifurcation lesion $=6$, and renal insufficiency $=6$. It was found that occurrence of ST in patients with a score $<6$ was $0.3 \%$, whereas in patients with a score $>13$, the risk of ST was $16.2 \%$. Such findings may facilitate decision-making regarding perioperative management in terms of hospital admissions both before and after surgery, and required modification of antiplatelet therapy.

Stent thrombosis has been associated with resistance to antiplatelet medication. Impaired response to antiplatelet therapy with aspirin using optical aggregometry has been demonstrated in patients with ST. Additional treatment with clopidogrel was not able to overcome this impaired response. ${ }^{59}$ Resistance to clopidogrel and failure to metabolize clopidogrel to its active metabolite has also played a role in ST. ${ }^{60}$ However, currently, there is no confirmed association between low responsiveness to clopidogrel and thrombotic events. The optimal level of clopidogrel-induced platelet inhibition, which will correlate quantitatively with clopidogrel's ability to prevent atherothrombotic events, is still lacking. ${ }^{36}$

\section{Risk of coronary events if antiplatelet medica- tions are discontinued}

There are no reports which quantify the overall risk of coronary events with DES if antiplatelet medications are discontinued. However, several reports document ST occurrence when antiplatelet medications were withdrawn. In one report, after a prolonged course of antiplatelet therapy, discontinuation of treatment resulted in four episodes of DES thrombosis. In three of these cases, the drug was discontinued for non-cardiac surgery. ${ }^{61}$ Kaluza et al. showed that non-cardiac surgery soon after BMS placement (often requiring aspirin withdrawal) was linked to a very high rate of adverse events. ${ }^{62}$ A second report describes a patient who simultaneously received a BMS and a DES stent. ${ }^{63}$ Twelve weeks later, the patient underwent knee surgery. Postoperatively, the DES thrombosed, whereas the BMS was patent. A third case has been described where a patient with DES placement two weeks before surgery suffered a MI in the postanesthesia care unit due to ST. She had missed only one dose of aspirin and clopidogrel preoperatively. ${ }^{64}$

\section{Risk of perioperative bleeding if antiplatelet med- ications are continued}

No randomized prospective study has assessed the risk of hemorrhagic complications related to clopidogrel or the combination of clopidogrel plus aspirin when used immediately before non-cardiac surgery in patients with DES. In a study by Payne et al., a threeto fourfold increase in bleeding time was observed following two days of treatment with clopidogrel $75 \mathrm{mg}$ and aspirin $150 \mathrm{mg}$ in healthy volunteers. ${ }^{65}$ Another report by Chapman et al., described an elective abdominal aneurysm repair complicated by diffuse hemorrhage resulting from combined clopidogrel and aspirin therapy. ${ }^{66}$ One study showed that in hip surgery patients taking aspirin, the incidence of bleeding requiring postoperative blood transfusion was $0.6 \%{ }^{67}$ There have been isolated case reports of patients with perioperative bleeding undergoing surgery without discontinuation of antiplatelet therapy. One case involved a patient on dual antiplatelet therapy who underwent resection of a large goiter that was causing tracheal compression. Postoperatively, bleeding from the surgical site caused significant respiratory distress requiring tracheal intubation. No actively bleeding vessels were observed at the time of re-operation. ${ }^{68}$ Another case involved a patient who underwent carotid endarterectomy after significant transient ischemic attacks and minor intracerebral infarcts. Postoperatively, there was persistent bleeding from the patient's neck resulting in airway compression secondary to hematoma formation. ${ }^{68}$ For CABG, controversies persist. It has been shown that aspirin increases bleeding but does not increase homologous blood transfusion requirements in elective coronary bypass surgery. ${ }^{69,70}$ While one study states that clopidogrel within four days of coronary bypass surgery is associated with increased blood loss and re-operation related to bleeding, ${ }^{71}$ another study did not support these findings. ${ }^{72}$ The ACC/AHA guidelines recommend that in patients taking clopidogrel for whom CABG is planned, the drug should be withheld for at least five days unless the urgency for revascularization outweighs the risks of excessive bleeding. ${ }^{22}$

\section{Perioperative platelet transfusion and relevance to DES}

At present, there are no studies or data related to perioperative platelet transfusion in patients with DES who are receiving antiplatelet drug therapy.

In the absence of platelet dysfunction, the standard hemorrhagic risk threshold for surgery is a platelet count of $50,000 \cdot \mu \mathrm{L}^{-1} \cdot{ }^{73-76}$ For neurosurgery and ophthalmologic surgery involving the posterior segment of the eye, a platelet count (PC) of $100,000 \cdot \mu \mathrm{L}^{-1}$ is recommended. ${ }^{77} \mathrm{~A}$ PC of $50,000 \cdot \mu \mathrm{L}^{-1}$ is sufficient for spinal anesthesia whereas a minimum PC of $80,000 \cdot \mu \mathrm{L}^{-1}$ has been proposed for epidural anesthesia. ${ }^{78-82}$

It may be difficult to assess the effectiveness of platelet transfusions. One platelet concentrate usu- 
ally produces an increase of about 7,000 to 10,000 platelets. $\mathrm{mm}^{-3}$ one hour after transfusion in a $70-\mathrm{kg}$ adult. ${ }^{83}$ However, many factors, including splenomegaly, previous sensitization, fever, sepsis, and active bleeding, may lead to decreased survival and decreased recovery of transfused platelets. ${ }^{84}$

According to the American Society of Anesthesiologists Task Force 2, platelet transfusion may be indicated despite an apparently adequate PC if there is known platelet dysfunction and microvascular bleeding. However, there are no recommendations for prophylactic platelet transfusions when antiplatelet medication has not been discontinued in a timely manner. ${ }^{84}$ There are no clinical studies describing the benefits of platelet transfusions or in limiting bleeding when bleeding occurs in patients with drug-induced thrombopathy. ${ }^{84}$ However, in severe hemorrhage, platelet transfusion may be an important therapeutic component in restoring the hemostatic mechanism. ${ }^{84}$

\section{Novel antiplatelet medications with potential implications for DES}

It would be convenient for patients with DES if there were a suitable antiplatelet agent that had requisite potency with a predictably short onset and offset of action. The patient could stop the long-acting antiplatelet agent and switch to the short-acting, reversible agent preoperatively. Levels of platelet inhibition could be monitored using selective P2Y12 assays. The shortacting, reversible agent could be continued until just before surgery and re-started immediately postoperatively. This would be analogous to stopping warfarin before surgery in patients with mechanical valves, starting iv heparin, then stopping heparin before surgery. Alternatively, the short-acting, reversible agent could be continued throughout the surgical procedure and stopped if the intraoperative bleeding warranted allogenic blood and/or blood product transfusions.

Interestingly, such drugs are under investigation (Table II). Cangrelor (AR-C69931MX) and AZ$6140^{85,86}$ are new P2Y12 competitive antagonists that are currently undergoing preclinical and clinical studies. ${ }^{87}$ Cangrelor ${ }^{87,88}$ is an adenosine $5^{\prime}$ triphosphate derivative, suitable for iv use. It produces reversible dose-dependent inhibition of platelet activation and aggregation. It has a plasma half-life of less than nine minutes, ${ }^{89}$ and recovery of platelet function takes place in less than $60 \mathrm{~min}$. It is likely to be launched in 2007-2008. This drug may also prove beneficial for patients on concomitant heparin therapy. Heparin potentiates the response to ADP and other agonists. Adenosine diphosphate receptor antagonists such as cangrelor inhibit the thrombogenic potentiation of heparin. ${ }^{90}$ AZD-6140 is suitable for oral administration. It has a fast onset of action. Prasugrel, ${ }^{91-94}$ another oral thenopyridine derivative, irreversibly inhibits the P2Y12 receptor. It has a faster onset of action than clopidogrel and is a more potent drug. These compounds were structured with the hope of possessing higher levels of inhibition of platelet aggregation, lesser variability of response than clopidogrel, and a lower incidence of drug resistance.

Several other drugs are also currently under investigation. MPalphaC, an inhibitor of 14-3-3zeta GPIbalpha interactions, which mediates von Willebrand factor binding to GPIb-IX, may be useful in treating or preventing thrombosis. ${ }^{95} \mathrm{~A}$ nitric oxide-releasing aspirin, NCX-4016 Nitroaspirin, exerts a wide range of antiplatelet activity, superior antithrombotic activity, and reduces restenosis after arterial injury in animals. It has been more effective as an antiplatelet regimen with clopidogrel, as compared to aspirin. ${ }^{96}$

\section{Conclusions}

Drug-eluting stents have rapidly evolved and become established therapy for patients with coronary anatomy amenable to PCI. There are important implications for anesthesiologists in planning the perioperative care of patients with DES. Delayed re-endothelialization may render both SES and PES susceptible to thrombosis for a longer duration than BMS. Stent thrombosis may be associated with resistance to antiplatelet medications. In patients with a DES, a preoperative cardiology consultation is essential. Elective surgery should be postponed if the duration between DES placement and non-cardiac surgery is less than six months. For semi-emergent procedures, both aspirin and clopidogrel should be continued during surgery unless contraindicated by the hemorrhagic potential of the procedure. If the risk of bleeding is high, then modification of the antiplatelet drug regimen should be considered on a case-by-case basis.

\section{Acknowledgements}

We are grateful to Pinak B. Shah MD, (Department of Cardiovascular Medicine and Interventional Cardiology, Caritas St. Elizabeth's Medical Center, Boston, M.A., USA) for his assistance in the preparation of this manuscript. We thank Mary Jo Dwyer, Department of Anesthesia, Caritas St. Elizabeth's Medical Center, Boston, M.A., USA for proofreading, and E.M. Cameron MD (Department of Anesthesia, Lahey Clinic, Burlington, M.A., USA) for his review of the manuscript. 


\section{References}

1 Hodgson JM, Klein LW, Bottner R, et al. SCAI Drugeluting Stent Task Force. Final report and recommendations of the working committees on cost effectiveness/economics, medical-legal issues and access to care, Catheter Cardiovasc Interv 2004; 62: $1-17$.

2 Iakovou I, Schmidt T, Bonnizoni E, et al. Incidence, predictors, and outcome of thrombosis after successful implantation of drug-eluting stents. JAMA 2005; 293 : 2126-30.

3 Presbitero $P$, Boccuzzi G. Restenosis treatment in the drug-eluting stent era. Ital Heart J 2005; 6: 514-21.

4 Eagle KA, Berger PB, Calkins H, et al. ACC/AHA Guideline Update for Perioperative Cardiovascular Evaluation for Noncardiac Surgery - Executive Summary. A report of the American College of Cardiology/American Heart Association Task Force on Practice Guidelines (Committee to Update the 1996 Guidelines on Perioperative Cardiovascular Evaluation for Noncardiac Surgery). Anesth Analg 2002; 94 : 1052-64.

5 Serruys PW, Luijten HA, Beatt KJ, et al. Incidence of restenosis after successful coronary angioplasty: a timerelated phenomenon. A quantitative angiographic study in 342 consecutive patients at 1, 2, 3, and 4 months. Circulation 1988; 77: 361-71.

6 Liuzzo JP, Abrose JA, Coppala JT. Sirolimus - and taxol-eluting stents differ towards intimal hyperplasia and re-endothelialization. J Invasive Cardiol 2005; 17 : 497-502.

7 Silber S, Albertsson P, Aviles FF, et al. Guidelines for percutaneous coronary interventions. The Task Force for Percutaneous Coronary Interventions of the European Society of Cardiology. Eur Heart J 2005; 26: 804-47.

8 Curfman GD. Sirolimus-eluting coronary stents. N Engl J Med 2002; 346: 1770-1.

9 Rogers CD. Drug-eluting stents: clinical perspectives on drug and design differences. Rev Cardiovasc Med 2005; 6(Suppl 1): S3-12.

10 Smith EJ, Rothman MT. Antiproliferative coatings for the treatment of coronary heart disease: what are the targets and which are the tools? J Interv Cardiol 2003: 16: $475-83$.

11 Moliterno DJ. Healing Achilles-sirolimus versus paclitaxel. N Engl J Med 2005; 353: 724-7.

12 Mauri L, Reisman M, Buchbinder M, et al. Comparison of rotational atherectomy with conventional balloon angioplasty in the prevention of restenosis of small coronary arteries: results of the Dilatation vs Ablation Revascularization Trial Targeting Restenosis (DART). Am Heart J 2003; 145: 847-54.
13 Stone GW, Ellis $S G$, Cox DA, et al. One-year clinical results with the slow-release, polymer-based, paclitaxeleluting TAXUS stent: the TAXUS-IV trial. Circulation 2004; 109: 1942-7.

14 Holmes DR Jr, Leon MB, Moses JW, et al. Analysis of 1 year clinical outcomes in the SIRIUS trial: a randomized trial of a sirolimus-eluting stent versus a standard stent in patients at high risk for coronary restenosis. Circulation 2004; 109: 634-40.

15 Buellesfeld L, Grube E. ABT-578-eluting stents. The promising successor of sirolimus- and paclitaxel-eluting stent concepts? Herz 2004; 29: 167-70.

16 Kastrati A, Dibra A, Eberle S, et al. Sirolimus-eluting stents vs paclitaxel-eluting stents in patients with coronary artery disease: meta-analysis of randomized trials. JAMA 2005; 294: 819-25.

17 Stone GW, Ellis SG, Cannon L, et al.; TAXUS V investigators. Comparison of a polymer-based paclitaxeleluting stent with a bare metal stent in patients with complex coronary artery disease: a randomized controlled trial. JAMA 2005; 14:294: 1215-23.

18 Patrono C, Bachmann F, Baigent C, et al. Expert consensus document on the use of antiplatelet agents. The task force on the use of antiplatelet agents in patients with atherosclerotic cardiovascular disease of the European society of cardiology. Eur Heart J 2004; 25: 166-81.

19 Gachet $C$. The platelet P2 receptors as molecular targets for old and new antiplatelet drugs. Pharmacol Ther 2005; 108: 180-92.

20 Rozalski M, Nocun M, Watala C. Adenosine diphosphate receptors on blood platelets - potential new targets for antiplatelet therapy. Acta Biochim Pol 2005; 52: 411-5.

21 Boeynaems JM, van Giezen H, Savi P, Herbert JM. P2Y receptor antagonists in thrombosis. Curr Opin Investig Drugs 2005; 6: 275-82.

22 Antman EM, Anbe DT, Armstrong PW, et al. ACC/ AHA guidelines for the management of patients with ST-elevation myocardial infarction; a report of the American College of Cardiology/American Heart Association Task Force on Practice Guidelines. (Committee to Revise the 1999 Guidelines for the Management of patients with acute myocardial infarction) J Am Coll Cardiol 2004: 44: 671-719.

23 Schwartz L, Bourassa MG, Lesperance J, et al. Aspirin and dipyridamole in the prevention of restenosis after percutaneous transluminal coronary angioplasty. $\mathrm{N}$ Engl J Med 1988; 318: 1714-9.

24 Peters RJ, Mehta SR, Fox KA, et al. Effects of aspirin dose when used alone or in combination with clopidogrel in patients with acute coronary syndromes: observations from the Clopidogrel in Unstable angina to 
prevent Recurrent Events (CURE) study. Circulation 2003; 108: 1682-7.

25 Jimenez AH, Stubbs ME, Tofler GH, Winther K, Williams GH, Muller JE. Rapidity and duration of platelet suppression by enteric-coated aspirin in healthy young men. Am J Cardiol 1992; 69: 258-62.

26 Bertrand ME, Rupprecht $H$, Urban A Gershlick AH, Investigators FT. Double-blind study of the safety of clopidogrel with and without a loading dose in combination with aspirin compared with ticlopidine in combination with aspirin after coronary stenting: the clopidogrel aspirin stent international cooperative study (CLASSICS). Circulation 2000; 102: 624-9.

27 Schomig A, Neumann FJ, Kastrati A, et al. A randomized comparison of antiplatelet and anticoagulant therapy after the placement of coronary-artery stents. N Engl J Med 1996; 334: 1084-9.

28 Fischman DL, Leon MB, Baim DS, et al. A randomized comparison of coronary-stent placement and balloon angioplasty in the treatment of coronary artery disease. Stent Restenosis Study Investigators. N Engl J Med 1994; 331: 496-501.

29 Leon MB, Baim DS, Popma JJ, et al. A clinical trial comparing three antithrombotic-drug regimens after coronary-artery stenting. Stent Anticoagulation Restenosis Study Investigators. N Engl J Med 1998; 339: 1665-71.

30 Rubboli A, Milandri M, Castelvetri C, Cosmi B. Metaanalysis of trials comparing oral anticoagulation and aspirin versus dual antiplatelet therapy after coronary stenting. Clues for the management of patients with an indication for long-term anticoagulation undergoing coronary stenting. Cardiology 2005; 104: 101-6.

31 Akbulut M, Ozbay $\Upsilon$, Karaca I, Ilkay E, Gundogdu $O$, Arslan N. The effect of long-term clopidogrel use on neointimal formation after percutaneous coronary intervention. Coron Artery Dis 2004; 15: 347-52.

32 Smith SC Jr, Feldman TE, Hirschfeld JW Jr, et al. ACC/AHA /SCAI 2005 guideline update for percutaneous coronary intervention: a report of the American College of Cardiology/American Heart Association Task Force on Practice Guidelines (ACC/AHA/SCAI Writing Committee to Update 2001 Guidelines for Percutaneous Coronary Intervention). Circulation 2006: 113: el66-286.

33 von Mach MA, Eich A, Wielemann LS, Munzel T. Subacute coronary stent thrombosis in a patient developing clopidogrel associated thrombotic thrombocytopenic purpura. Heart 2005; 91: el4.

34 Hankey GJ, Eikelboom JW. Aspirin resistance. Lancet 2006; 367: 606-17.

35 Wiviott SD, Antman EM. Clopidogrel resistance: a new chapter in a fast-moving story. Circulation 2004; 109:
$3064-7$.

36 Nguyen TA, Diodati JG, Pharand C. Resistance to clopidogrel: a review of the evidence. J Am Coll Cardiol 2005; 45: 1157-64.

37 Jaremo P, Lindabl TL, Fransson SG, Richter A. Individual variations of platelet inhibition after loading doses of clopidogrel. J Intern Med 2002; 252: 233-8.

38 Gurbel PA, Bliden KP, Hiatt BL, O'Connor CM. Clopidogrel for coronary stenting: response variability, drug resistance, and the effect of pretreatment platelet reactivity. Circulation 2003; 107: 2908-13.

39 Muller I, Besta F, Schulz C, Massberg S, Schonig A, Gawaz M. Prevalence of clopidogrel non-responders among patients with stable angina pectoris scheduled for elective coronary stent placement, Thromb Haemost 2003; 89: 783-7.

40 Mobley JE, Bresee SJ, Wortham DC, Craft RM, Snider $C C$, Carroll RC. Frequency of nonresponse antiplatelet activity of clopidogrel during pretreatment for cardiac catheterization. Am J Cardiol 2004; 93: 456-8.

41 Angiolillo DJ, Fernandez-Ortiz A, Bernardo E, et al. Platelet aggregation according to body mass index in patients undergoing coronary stenting: should clopidogrel loading-dose be weight adjusted? J Invasive Cardiol 2004; 16: 169-74.

42 Serebruany VL, Steinhubl SR, Berger PB, Malinin AI, Bhatt DL, Topol, EJ. Variability in platelet responsiveness to clopidogrel among 544 individuals. J Am Coll Cardiol 2005; 45: 246-51.

43 Matetzky S, Shenkman B, Guetta V, et al. Clopidogrel resistance is associated with increased risk of recurrent atherothrombotic events in patients with acute myocardial infarction. Circulation 2004; 109: 3171-5.

44 Geiger J, Teichmann L, Grossman R, et al. Monitoring of clopidogrel action: comparison of methods. Clin Chem 2005; 51: 957-65.

45 Eagle KA, Guyton RA, Davidoff R, et al. ACC/AHA 2004 guideline update for coronary artery bypass graft surgery: report of the American College of Cardiology/American Heart Association Task Force on Practice Guidelines (Committee to Update the 1999 Guidelines for Coronary Artery Bypass Graft Surgery). Circulation 2004: 110: e340-437.

46 Takahara $M$, Usuba A, Endou G, et al. Evaluation of factors aggravating and delaying recovery from postoperative hypercoagulable state in patients operated on for esophageal cancer (Japanese). Nippon Kyobu Geka Gakkai Zasshi 1993; 41: 1133-42.

47 Eagle KA, Berger PB, Calkins H, et al. ACC/AHA guideline update for perioperative cardiovascular evaluation for noncardiac surgery -- executive summary: a report of the American College of Cardiology/ American Heart Association Task Force on Practice 
Guidelines (Committee to Update the 1996 Guidelines on Perioperative Cardiovascular Evaluation for Noncardiac Surgery). J Am Coll Cardiol 2002; 39: 542-53.

48 Horlocker TT, Wedel DJ, Benzon H, et al. Regional anesthesia in the anticoagulated patient: defining the risks (the second ASRA Consensus Conference on Neuraxial Anesthesia and Anticoagulation). Reg Anesth Pain Med 2003; 28: 172-97.

49 Rodriguez AE, Mieres J, Fernandez-Pereira C, et al. Coronary stent thrombosis in current drug-eluting stent era: insights from ERACI III trial. J Am Coll Cardiol 2006; 47: 205-7.

50 Cutlip DE, Baim DS, Ho KK, et al. Stent thrombosis in the modern era: a pooled analysis of multicenter coronary stent clinical trials. Circulation 2001; 103 : 1967-71.

51 Karvouni E, Korovesis S, Katritsis DG. Very late thrombosis after implantation of sirolimus eluting stent. Heart 2005; 91: e45.

52 Lee CH, Tan HC, Ong HY, Teo SG, Lim YT. Late thrombotic occlusion of paclitaxel eluting stent more than one year after stent implantation. Heart 2004; 90: 1482 .

53 McFadden EP, Stabile E, Regar E, et al. Late thrombosis in drug-eluting coronary stents after discontinuation of antiplatelet therapy. Lancet 2004; 364: 1519-21.

54 Moreno R, Fernandez C, Hernandez R, et al. Drugeluting stent thrombosis: results from a pooled analysis including 10 randomized studies. J Am Coll Cardiol 2005; 45: 954-9.

55 Farb A, Burke AP, Kolodgie FD, Virmani R. Pathological mechanisms of fatal late coronary stent thrombosis in humans. Circulation 2003; 108: 17016.

56 Ong AT, McFadden EP, Regar E, de Jaegere PP, van Domburg RT, Serruys PW. Late angiographic stent thrombosis (LAST) events with drug-eluting stents. J Am Coll Cardiol 2005; 45: 2088-92.

57 Ortolani P, Ardissino D, Cavallini C, et al. Effect of sirolimus-eluting stent in diabetic patients with small coronary arteries (a SES-SMART substudy). Am J Cardiol 2005; 96: 1393-8.

58 Iakovou I, Agostoni P, Biondi-Zoccai G, et al. A simple risk score for prediction of thrombosis after drug-eluting stent implantation. European Society of Cardiology Congress 2005; 3749 (abstract).

59 Wenaweser P, Dorffler-Melly J, Imboden K, et al. Stent thrombosis is associated with an impaired response to antiplatelet therapy. J Am Coll Cardiol 2005; 45 : 1748-52.

60 von Beckerath N, Taubert D, Pogatsa-Murray G, et al. A patient with stent thrombosis, clopidogrel-resistance and failure to metabolize clopidogrel to its active metabolite. Thromb Haemost 2005; 93: 789-91.

61 Satler LF. Recommendations regarding stent selection in relation to the timing of noncardiac surgery postpercutaneous coronary intervention. Catheter Cardiovasc Interv 2004; 63: 146-7.

62 Kaluza GL, Joseph J, Lee JR, Raizner ME, Raizner AE. Catastrophic outcomes of noncardiac surgery soon after coronary stenting. J Am Coll Cardiol 2000; 35: 1288-94.

63 Auer J, Berent R, Weber T, Eber B. Risk of noncardiac surgery in the months following placement of drugeluting coronary stent (Letter). J Am Coll Cardiol 2004; 43: 713.

64 Murphy JT, Faby BG. Thrombosis of sirolimus-eluting coronary stent in the postanesthesia care unit. Anesth Analg 2005; 101: 971-3.

65 Payne DA, Hayes PD, Jones CI, Belham P, Naylor AR, Goodall $A H$. Combined therapy with clopidogrel and aspirin significantly increases the bleeding time through a synergistic antiplatelet action. J Vasc Surg 2002; 35: 1204-9.

66 Chapman TW, Bowley DM, Lambert AW, Walker AJ, Ashley SA, Wilkins DQ. Haemorrhage associated with combined clopidogrel and aspirin therapy. Eur J Vasc Endovasc Surg 2001; 22: 478-9.

67 Anonymous. Prevention of pulmonary embolism and deep vein thrombosis with low dose aspirin: Pulmonary Embolism Prevention (PEP) trial. Lancet 2000; 355: 1295-302.

68 Moore $M$, Power $M$. Perioperative hemorrhage and combined clopidogrel and aspirin therapy. Anesthesiology 2004; 101: 792-4.

69 Reich DL, Patel GC, Vela-Cantos F, Bodian C, Lansman $S$. Aspirin does not increase homologous blood requirements in elective coronary bypass surgery. Anesth Analg 1994; 79: 4-8.

70 Rawitscher RE, Jones JW, McCoy TA, Lindsley DA. A prospective study of aspirin's effect on red blood cell loss in cardiac surgery. J Cardiovasc Surg (Torino) 1991; 32: 1-7.

71 Chu MW, Wilson SR, Novick RJ, Stitt LW, Quantz MA. Does clopidogrel increase blood loss following coronary artery bypass surgery? Ann Thorac Surg 2004; 78: 1536-41

72 Karabulut H, Toraman F, Evrenkaya S, Goksel O, Tarcan $S$, Alhan C. Clopidogrel does not increase bleeding and allogenic blood transfusion in coronary artery surgery. Eur J Cardiothorac Surg 2004; 25: 419-23.

73 Anonymous. Practice parameter for the use of fresh-frozen plasma, cryoprecipitate, and platelets. Fresh-Frozen Plasma, Cryoprecipitate, and Platelets Administration Practice Guidelines Development Task Force of the 
College of American Pathologists. JAMA 1994; 271: 777-81.

74 Rebulla P. Trigger for platelet transfusion. Vox Sang 2000; 78(Suppl 2): 179-82.

75 Murphy MF, Brozovic B, Murphy W, Ouwehand W, Waters $A H$. Guidelines for platelet transfusions. British Committee for Standards in Haematology, Working Party of the Blood Transfusion Task Force. Transfus Med 1992; 2: 311-8.

76 Contreras $M$. Final statement from the consensus conference on platelet transfusion. Transfusion 1998; 38: 796-7.

77 Hay A, Olsen KR, Nicholson DH. Bleeding complications in thrombocytopenic patients undergoing ophthalmic surgery. Am J Ophtalmol 1990; 109: 4823.

78 Rolbin SH, Abbott D, Musclow E, Papsin F, Lie LM, Freedman J. Epidural anesthesia in pregnant patients with low platelet counts. Obstet Gynecol 1988; $71(6$ Pt 1): 918-20.

79 Edelson RN, Chernik NL, Posner JB. Spinal subdural hematomas complicating lumbar puncture. Arch Neurol 1974; 31: 134-7.

80 Beilin $\Upsilon$, Zabn J, Comerford M. Safe epidural analgesia in thirty parturients with platelet counts between 69,000 and 98,000 mm(-3). Anesth Analg 1997; 85: 385-8.

81 Hew-Wing P, Rolbin SH, Hew E, Amato D. Epidural anaesthesia and thrombocytopenia. Anaesthesia 1989; 44: 775-7.

82 Vandermeulen EP, Van Aken H, Vermylen J. Anticoagulants and spinal-epidural anaesthesia. Anesth Analg 1994; 79: 1165-77.

83 Miller RD. Transfusion therapy. In: Miller RD (Ed). Anesthesia, $6^{\text {th }}$ ed. New York: Elsevier; 2005: 1822-3.

84 Samama CM, Djoudi R, Lecompte T, Nathan-Denizot N, Schved JF; Agence Française de Sécurité Sanitaire des Produits de Santé expert group. Perioperative platelet transfusion: recommendations of the Agence Française de Sécurité Sanitaire des Produits de Santé (AFSSaPS) 2003. Can J Anesth 2005; 52: 30-7.

85 Husted S, Emanuelsson H, Heptinstall S, Sandset PM, Wickens M, Peters G. Pharmacodynamics, pharmacokinetics, and safety of the oral reversible P2Y12 antagonist AZD6140 with aspirin in patients with atherosclerosis: a double-blind comparison to clopidogrel with aspirin. Eur Heart J 2006; 27: 1038-47.

86 van Giezen JJ, Humphries RG. Preclinical and clinical studies with selective reversible direct P2Y12 antagonists. Semin Thromb Hemost 2005; 31: 195-204.

87 Behan MW, Fox SC, Heptinstall S, Storey RA. Inhibitory effects of P2Y12 receptor antagonists on TRAP-induced platelet aggregation, procoagulant activity, micro- particle formation and intracellular calcium responses in patients with acute coronary syndromes. Platelets 2005; 16: 73-80.

88 Chattaraj SC. Cangrelor AstraZeneca. Curr Opin Investig Drugs 2001; 2: 250-5.

89 Storey RF, Oldroyd KG, Wilcox RG. Open multicentre study of the P2T receptor antagonist AR-C69931MX assessing safety, tolerability and activity in patients with acute coronary syndromes. Thromb Haemost 2001; 85: 401-7.

90 Storey RF, May JA, Heptinstall S. Potentiation of platelet aggregation by heparin in human whole blood is attenuated by P2Y12 and P2Y1 receptor antagonists but not aspirin. Thromb Res 2005; 115: 301-7.

91 Niitsu Y, Sugidachi A, Hasegawa M, et al. CS-747 (Prasugrel, LY640315), a novel antiplatelet agent inhibits arterial thrombosis through selective blockade of platelet P2Y12 receptors. J Thromb Haemost 2005; 3(Suppl 1): 1708.

92 Niitsu Y, Jakubowski JA, Sugidachi A, Asai F. Pharmacology of CS-747 (prasugrel, LY640315), a novel, potent antiplatelet agent with in vivo P2Y12 receptor antagonist activity. Semin Thromb Hemost 2005; 31: 184-94.

93 Sugidachi A, Asai F, Ogawa 7, Inoue T, Koike H. The in vivo pharmacological profile of CS-747, a novel antiplatelet agent with platelet ADP receptor antagonist properties. Br J Pharmacol 2000; 129: 1439-46.

94 Wiviott SD, Antman EM, Winters K, et al.

Randomized comparison of prasugrel (CS-747, LY640315), a novel thienopyridine P2Y12 antagonist, with clopidogrel in percutaneous coronary intervention: results of the Joint Utilization of Medications to Block Platelets Optimally (JUMBO)-TIMI 26 trial. Circulation. 2005; 111: 3366-73.

95 Dai K, Bodnar R, Berndt MC, Du X. Critical role for 14-3-3zeta protein in regulating the VWF binding function of platelet glycoprotein Ib-IX and its therapeutic implications. Blood 2005; 106: 1975-81.

96 Momi S, Pitchford SC, Alberti PF, Minuz P, Del Soldato $P$, Gresele P. Nitroaspirin plus clopidogrel versus aspirin plus clopidogrel against platelet thromboembolism and intimal thickening in mice. Thromb Haemost 2005; 93: $535-43$. 